\title{
DETECTION OF ASTROVIRUS-LIKE IN DIARRHOEIC STOOL AND ITS COEXISTENCE WITH ROTAVIRUS
}

\author{
C. M. NOZAWA, M. G. S. VAZ and M. A. A. M. GUIMARāeS
}

\section{S U M M A R Y}

A clinical case is described in this paper in that a 5-month old baby girl severely malnourished and dehydrated presented a prolonged acute diarrhoea. No enteropathogenic bacteria or parasites were demonstrated. Virological study by electron microscopy (EM) showed that the patient shed both astrovirus-like and rotavirus in the watery stool as long as 12 days after the onset. Immune electron microscopy (IEM) performed with the patient serum revealed clumps of both viruses. It is suggest that this may be a case of mixed infection due to astrovirus-like and rotavirus.

\section{N T R O D U C T I O N}

Astrovirus is one of the viruses associated to acute diarrhoea in childhood. It was first described in 1975 in faeces of newborn babies with diarrhoea, although it was also found in symptomless babies ${ }^{8}$. Astrovirus has since then being found associated to diarrhoea episodes. A strong evidence that the virus is a human en teric pathogen came from the findings that lamb astrovirus induced diarrhoea in young lambs ${ }^{13}$.

The identification of astrovirus rests upon its morphologic features by electron microscopic (EM) observation for the time being ${ }^{12}$. The 28-nm virus particles resemble fiver-or sixpointed star.

Likely others intestinal viruses, e.g. rotavirus, astrovirus seems to have a worldwide distribution.

In Brazil astrovirus was recently described in a study of viral diarrhoea 5 . In our laboratory we detected astrovirus-like in diarrhoeic stool coexisting with rotavirus. The importance of astrovirus as an aetiologic agent in infant diarrhoea and the procedure for EM visualization are discussed is this paper.

\section{MATERIAL AND METHODS}

Diarrhoeic stool was collected from L.C.B. a 5-month old female baby twelve days after the onset of the diarrhoea. The child had fever, vomiting and evacuated five to ten times a day. Watery stool had either no blood or mucous. L.C.B. was severely malnourished and dehydrated. Virological, bacteriological and parasitolo. gical studies were carried out. Paired blood samples were also collected.

For the virological study electron microscopy (EM) was carried out and the watery stool sample was treated as following: a small volume of the material was diluted with a drop of distilled water in a glass slide. A drop of the suspension was deposited on a Formvar-precoated EM grid and negatively stained with $2 \%$ PTA, $\mathrm{pH}=6.5$ and washed twice with distilled water after the staining. This procedure is referred to super direct electron microscopy (SD) in the present work. An additional volume of faeces was diluted at $10-20 \%(\mathrm{v} / \mathrm{v})$ with PBS and shaken for 5 minutes with glass beads. 0.5 $\mathrm{ml}$ of the clarified supernatant $(4000 \mathrm{~g}, 15 \mathrm{mi}$ nutes at $4^{\circ} \mathrm{C}$ ) 'was added to $0.2 \mathrm{ml}$ of $10 \% \mathrm{hu}$ man immune globulin (HIG), U.S.P., Gammar,

Department of Virology. IM/UFRJ. Caixa Postal 68.040 - 21.944 Rio de Janeiro - RJ - Brazil 
NOZAWA, C. M.; VAZ, M. G. S. \& GUIMARAeS, M. A. A. M. - Detection of Astrovirus-like in diarrhoeic stool ant its coexistence with Rotavirus, Rev. Inst, Med. trop. São Paulo 27:238-241, 1985.

Armour Pharm. Co., Arizona, USA and incubated at $37^{\circ} \mathrm{C}$ for 1 hour. The mixture was spun down at $12000 \mathrm{~g}$ for 1 hour. The pellet was resuspended with three drops of distilled water and negatively stained for EM. The latter procedure was also performed with the undiluted patient's second serum sample instead of HIG. The observation was carried out in a Philips 301 electron microscope.

\section{RESULTS}

The study of the patient material by the super direct electron microscopy (SD) showed a large number of rotavirus particles averaging 0.5 particles per mesh. Although the grids were thoroughly screened no other viral particles were observed. The immune electron microscopy (IEM) performed with HIG revealed several clumps of astrovirus-like (Fig. 1) and rotavirus.

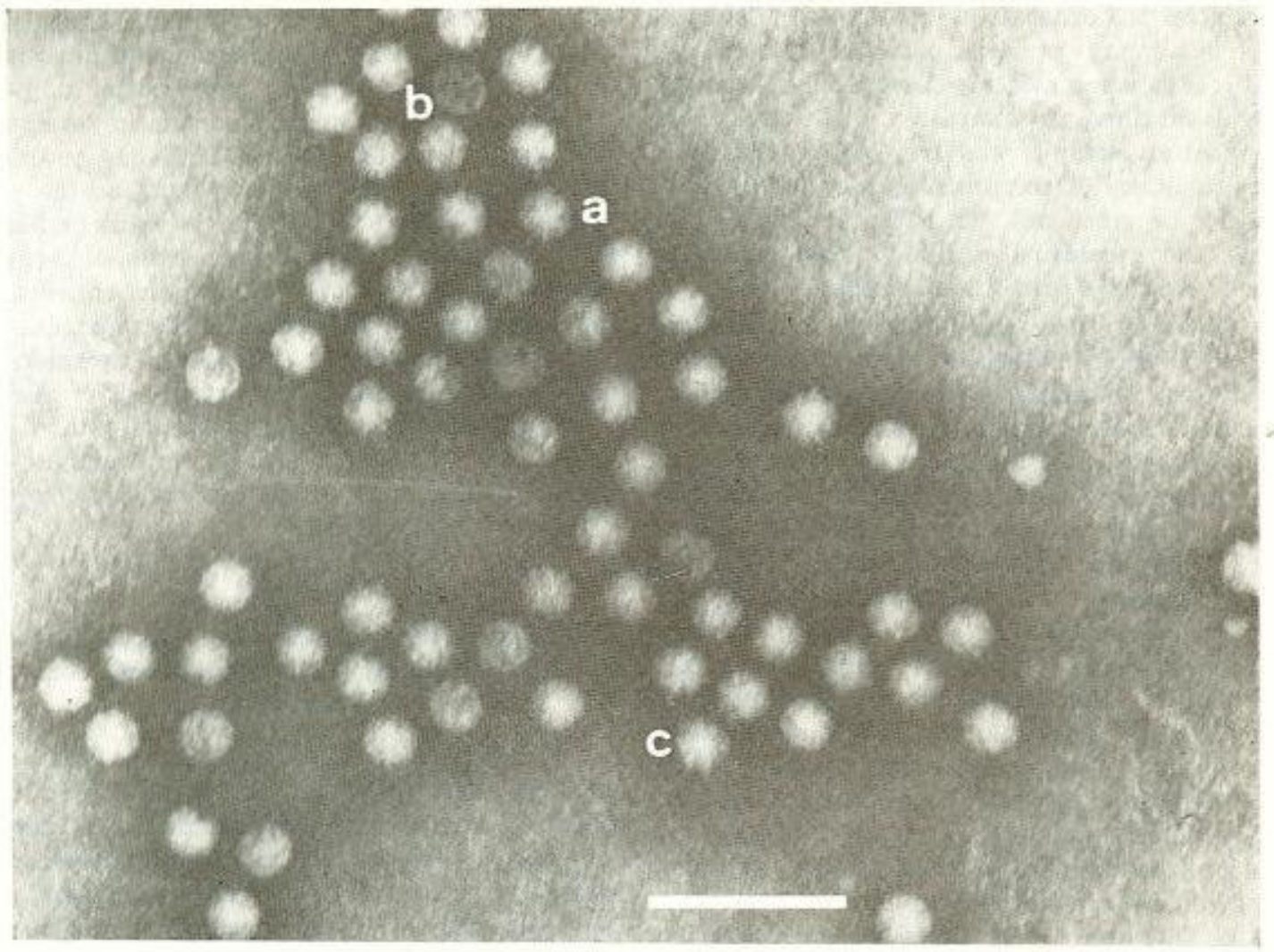

Fig. I - Electron nicrograph of astrovirus-l1ke particles Iound in L.C.B. faeces. Note 5.pointed star foature in some particles. Bar: 100nm

The IEM carried out with the second serum also showed clumps of the viruses. Either IEM or SD showed no other virus. Most rotavirus particles observed in these preparations were complete but electron dense empty forms were also found (not shown). Astrovirus-like presented the peculiar structure of 5-pointed star in about $10 \%$ of the total number of particles (Fig. 1). Some particles seemed to be empty but nervertheless the star points could be seen (a) and others had a smooth contour with structure that may correspond to the star points (b). Furthermore a few particles (c) showed a peculiar contour in that tips of the star points are beyond the particle edge.

\section{DISCUSSION}

The role played by rotavirus in infant diarrhoea is presently well settled down ${ }^{2}$. In Bra zil the virus was first described in $1976^{\circ}$ and since then it has been found in outbreaks of diarrhoea in school ${ }^{14}$, in an isolated indian community $^{7}$, and in sporadic cases ${ }^{1,11}$. The ca 
NOZAWA, C. M.; VAZ, M. G. S. \& GUIMARAES, M. A. A. M. - Detection of Astrovirus-like in diarrhoeic stool and its coexistence with Rotavirus. Rev. Inst. Med. trop. São Paulo 27:238-241, 1985.

se described in this study is an isolated one in which the child (L.C.B.) eliminated large number of rotavirus particles even after twelve days of the onset when the stool sample was collected. This might be an anusual feature in rotaviral infection for most cases virus particles are shed in large number in the first four days, morever clinically it lasted longer than usual ${ }^{15}$. It is unlikely that enteropathogenic bacteria or parasite were involved before the viral infection for none of these agents were detected seven days after the onset of the diarrhoea. The findings that many rotavirus particles were clumped by IEM using patients second serum sample reveals antibody response to the virus. The first serum sample was not tested. However the possibility of the antibody rise in the past can not be ruled out. On the other hand it is likely that maternal antibody may not last longer than two-three months after birth.

Concerning the astrovirus as an enteropathogenic agent, evidences showed that adult volunteers developed vomiting and diarrhoea, and shed large number of astrovirus particles after experimental ingestion of faecal filtrate containing astrovirus ${ }^{4}$. Furthermore virus-specific antibody rises were detected in volunteers ${ }^{12}$. We have also found that L.C.B. shed large number of astrovirus-like particles and patient's serum sample also revealed to contain virus-specific antibody shown by viral clumping in IEM. It was found that astroviral infection like rotaviral infection is self-limited and the former lasted in average 12 hours ${ }^{3}$. This study shows that viral shedding may last far longer which may also be an anusual feature. The long lasting clinical manifestation and the viral shedding in both cases may well be due to the patient's severe state of malnutrition. A study on this aspects would be rather import.

On the diagnosis point of view EM techniques are unique for astroviral detection for the time being. We have found that SD technique is very useful for viruses sized $50-\mathrm{nm}$ and over for diarrhoeic faeces. Our experience has shown that rotavirus and adenovirus are fairly easy to be detected in spite of faecal debris. It is necessary however that grios be carefully washed with a few drops of distilled water in order to avoid overstaining. On the other hand smaller viruses sized 28-30nm may not be detected by SD mostly due to small round impurities or debris, which make difficult to differentiate them unless they are found in an excepcional number. Yet by IEM technique it is easier to find small viruses for the faecal material is diluted and clarified by centrifugation therefore the preparation is much clearer. However the loss of virus in faecal suspension due to sedimentation either by standing or centrifugation must be considered ', especially if the material is poor in virus content and if particles are preclumped. It has been shown that large-and medium-sized viruses even as a single particles may sediment at low gravitational force, e.g. $2.100 \mathrm{~g}{ }^{10}$. One mean to overcome this drawback is by visualizing a crude preparation such as by SD technique. Our experience in terms of the comparison of SD and IEM has revealed that the former technique in spite of the previously described limitation is more reliable than the latter. However an extensive study has to be carried out before any conclusion be drawn on the efficiency of SD technique in comparison to IEM. The use of commercial HIG in IEM is rather important for it allows clumping of other viruses especially in stool specimens, however a testing for the best dilution of HIG has to be carried out for the efficiency of the method.

\section{RESUMO}

\section{Detecção de vírus semelhante a Astrovírus em fezes diarrêicas e sua coexistência com Rotavírus}

É apresentado neste trabalho um caso clí nico de diarréia aguda prolongada em uma criança subnutrida e desidratada de 5 meses de idade. $O$ estudo virológico por microscopia eletrônica mostrou que a criança eliminava, pelas fezes aquosas, vírus semelhante, morfologi. camente, ao astrovirus e rotavirus. A presença destes vírus foi observada 12 dias após o início da diarréia. A imunomicroscopia eletrônica realizada com o soro da criança mostrou agrega. dos de ambos os vírus. Não foram detectadas bactérias ou parasitas enteropatogênicos. Os Autores sugerem que este pode ser um caso de infecção mista de vírus semelhante ao as trovírus e rotavírus.

\section{ACKNOWLEDGEMENTS}

We thank to FINEP, CNPq and CEPG/UFRJ for financial support and we also thank to Mrs. E. Martins for typing the manuscript and P.R. Rios for preparing the photograph. 
NOZAWA, C. M.; VAZ, M. G. S. \& GUIMARAES, M. A. A. M. - Detection of Astrovirus-like in diarrhoeic stool and its coexistence with Rotavirus. Rev. Inst. Med. trop. São Paulo 2\%:238-241, 1985.

\section{REFERENCES}

1. COELHO, C. A. R.; MOREIRA, F. L,; MAFFEI, F. V. L. \& COELHO, K. J. R. - Incidência de partículas virais em crianças com diarréia aguda ou protraída, atendidas no Hospital das Clínicas da Faculdade de Medicina de Botucatu, no periodo de fevereiro de 1980 a fevereiro de 1981. Rev. Inst. Med. trop. São Paulo 25: 113-119, 1983.

2. CUKOR, G. \& BLACKLOW, N. R. - Human viral gastroenteritis. Microbiol. Rev. 48: 157-179, 1984.

3. KONNO, T.; SUZUKI, H.; ISHIDA, N.; CHIBA, R.; MOCHIZUKI, R. \& TSUNODA, A. - Astrovirus-associated epidemic gastroenteritis in Japan. J. Med. Vi. rol. 9: 11-17, 1982.

4. KURTZ, J. B.; LEE, T. W.; CRAIG, J. W. \& REED, S. E. - Astrovirus infection in volunteers. J. Med. Virol. 3: 221-230, 1979.

5. LEITE, J. P. G. - Padronização de métodos para a detecção de adenovírus associados a gastrenterite. [Tese de Mestrado], Rio de Janeiro, FIOCRUZ, 1983.

6. LINḦARES, A. C.; PINHEIRO, F. P.; SCHMETZ, C.; MULLER, G. \& PETERS, D. - Duovirus (rotavirus) em Belém do Pará, Brazil. Rev. Inst. Med. trop. São Paulo 19: 278-279, 1977.

7. LINHARES, A. C.; PINHEIRO, F. P.; FREITAS, R B.; GABBAY, Y. B.; SHIRLEY, J. A. \& BEARDS, G. M. - An outbreak of rotavirus diarrhoea among a nonimmune isolated South American Indian Commu. nity. Am. J. Epidemiol. 113: 703-704, 1981.

8. MADELEY, C. R. \& COSGROVE, B. P. - Viruses in infantile gastroenteritis. Lancet 2: 124, 1975.
9. NARANG, H. K. \& CODD, A. A. - A low-speed centrifugation technique for the preparation of grids for direct virus examination by electron microscopy. $J$. Clin. Pathol. 32: 304-305, 1979.

10. NARANG, H. K. \& CODD, A. A. - Frequency of preclumped virus in routine fecal specimens from patients with acute nonbacteriol. J. Glin. Microbiol. 13: 982-988, 1981.

11. NOZAWA, C. M.; De GOES, P. \& LAMPE, E. - Rotavirus: Agente de diarréia infantil. An. Microbiol. 25: $19-36,1981$

12. REED, S. E.; KURTZ, J. B. \& LEE, T. W. - Ino culation of human volunteers with a human astrovirus. Abstracts of IV International Congress of Virology. The Hague, W35/7 p. 461, 1978.

13. SNODGRASS, D. R. \& GRAY, E. W. - Detection and transmission of $30-\mathrm{nm}$ virus particles (astrovirus) in faeces of lambs with diarrhoea. Arch. Virol. 55: 287$291,1977$.

14. SUTMOLLER, F.; AZEREDO, R. S.; LACERDA, M D.; BARTH, O. M.; PEREIRA, H. G.; HOFFER, E. \& SCHATZMAYR, H. G. - An outbreak of gastroenteritis caused by both rotavirus and $\mathbf{S}$. sonnei in a private school in Rio de Janeiro. J. Hyg. 88: 285-293, 1982.

15. VIRCH, C. J.; LEWIS, F. A.; KENNETT, M. L.; HOMOLA, M. ; PRITCHARD, H. \& GUST, I. D. - A study of the prevalence of rotavirus infection in children with gastroenteritis admitted to an Infectious Di sease Hospital. J. Med. Virol. 1: 69-77, 1977 ,

Recebido para publicação em 21/2/1985. 